до вантажовідправників, наявність кваліфікаційної робочої сили, що сприяє удосконаленню технічновиробничому процесу роботи вантажних перевезень, дозволить подальший розвиток економіки та сформує перспективне та стабільне функціонування галузі вантажних перевезень та держави в цілому.

\section{СПИСОК ЛІТЕРАТУРИ}

1. Бараш Ю.С. Управління залізничним транспортом країни. Монографія. / Ю.С. БарашДніпропетровьк, 2006. - 252 с

2. Дикань В.Л. Забезпечення ефективності інноваційної політики [Текст]. Монографія. / В.Л. Дикань-Харків, 2008. - 194 с.

3. Галабурда В.Г. Единая транспортная система./ В.Г.Галабурда. - М.: Транспорт, 1996. $295 \mathrm{c}$

4. Экономика железнодорожного транспорта: Учеб. Для вузов ж.-д./ Н.П.Терешиной,
Б.М.Лапидуса, М.Ф.Трихункова. - М.: УМК МПС России, 2001. -600 с.

5. Чорний В.В. Конкурентні переваги залізниць на ринку вантажних перевезень/ Чорний В.В. /Вісник ЧДТУ «Серія «Економічні науки» Науковий збірник. - 2012. - № 1(56).

6. SWOT-аналіз - основа формування маркетингових стратегій: Навчальний посібник/За ред. Л.В.Балабанової. - 2-ге вид., випр. і доп. - К.: Знання, 2005.-301 с.-(Вища освіта XXI ст.).

7. Офіційний сайт Державної Служби Статистики України [Електронний ресурс]. Режим доступу: http://ukrstat.org

8. Офіційний сайт Укрзалізниці [Електронний ресурс]. Режим доступу: http://www.uz.gov.ua/

9. Кушнир І.Ю. Ефективність вантажних залізничних перевезень України та іiї підвищення в умовах глобалізації. Автореферат дис. канд. наук [Текст] / I.Ю. Кушнир // Харків, УкрДАЗТ. - 2004. $18 \mathrm{c}$.

Рецензент д.е.н., професор УкрДАЗТ Познякова Л.О. Експерт редакційної колегії к.е.н., доцент УкрДАЗТ Полякова О.М.

УДК 338.47:658.8

\title{
ТЕНДЕНЦІЇ РОЗВИТКУ СУЧАСНОЇ ІНФРАСТРУКТУРИ ЗАЛІЗНИЧНОГО ТРАНСПОРТУ НА ОСНОВІ МАРКЕТИНГО-ЛОГІСТИЧНОГО ПІДХОДУ
}

\author{
Копитко В. І. д.е.н., професор, декан факультету Львівської філії (ДНУЗТ)
}

Розглядається маркетинго-логістичний підхід до розвитку сучасної інфраструктури на залізничному транспорті. Пропонується маркетинго-логістичне забезпечення розвитку інфраструктури, щчо буде спряти ефективному управлінню вантажопотоками та пасажиропотоками на залізницях з використанням комплексу взаємопов'язаних інформаційно-управлінських систем. Це дозволить здійснювати технологічний взаємозв'язок із суміжними організаціями транспортного процесу, шзо в подальиому сприятиме створенню інтегрованих транспортно-логістичних ланиюгів 3 урахуванням системних методів управління, спрямованих на досягнення сталого розвитку залізничої галузі. Ращіонально розміщені маркетинго-логістичні центри сприятимуть переходу на зорієнтовану на клієнта модель надання послуг пасажирських $i$ вантажних перевезень на інновачійній основі, використовуючи можливості розвитку державно-приватного партнерства в Украӥні.

Ключові слова: маркетинго-логістичний підхід, інфраструктура залізничного транспорту, оптимізація вантажопотоків та пасажиропотоків, маркетинго-логістичні центри, інновацї, державно-приватне партнерство.

\section{ТЕНДЕНЦИИ РАЗВИТИЯ СОВРЕМЕННОЙ ИНФРАСТРУКТУРЫ ЖЕЛЕЗНОДОРОЖНОГО ТРАНСПОРТА НА ОСНОВЕ МАРКЕТИНГО- ЛОГИСТИЧЕСКОГО ПОДХОДА}

Копитко В. И. д.э.н., профессор, декан факультета Львовского филиала (ДНУЖТ)

Рассматривается маркетингово-логистический подход развития современной инфраструктуры на железнодорожном транспорте. Предлагается маркетинго-логистическое обеспечение развития 
инфраструктуры, которая будет способствовать эффективному управлению грузопотоками $и$ пассажиропотоками на дорогах с использованием комплекса взаимосвязанных информационноуправленческих систем. Это позволит осуществлять технологическую взаимосвязь со смежными организачиями транспортного прочесса, что в дальнейшем будет способствовать созданию интегрированных транспортно-логистических цепей с учетом системных методов управления, направленных на достижение устойчивого развития железнодорожной отрасли. Рационально размещзенные маркетинго-логистические центры будут способствовать переходу на клиентоориентированную модель предоставления услуг пассажирских и грузовых перевозок на инновационной основе, используя возможности развития государственно-частного партнерства в Украине.

Ключевые слова: маркетинго-логистический подход, инфраструктура жселезнодорожсного транспорта, оптимизация грузопотоков и пассажиропотоков, маркетинго-логистические центры, инновации, государственно-частное партнерство.

\title{
TRENDS IN THE DEVELOPMENT OF MODERN RAILWAY INFRASTRUCTURE BASED ON MARKETING AND LOGISTICS APPROACH
}

\author{
Kopytko V.I. PhD, professor, dean of the L'viv branch \\ (Dnipropetrovsk National University of Railway Transport named after Academician V. Lazaryan)
}

The marketing and logistics infrastructure of the modern approach to rail transport is examined. The marketing and logistics providing development of infrastructure that will support effective management of cargo traffic and passenger flows on the rail using a complex of interrelated information - management systems is proposed. This technology allows providing the interconnection of related organizations of transport process, which further contribute to the creation of integrated transport and logistics chains based management system designed to achieve sustainable development of railway industry. Rationally are marketing and logistics centres will facilitate the transition to a customer-oriented service delivery model of passenger and freight traffic on the basis of innovation, using the potential of public-private partnership in Ukraine.

Keywords: marketing and logistics approach, railway infrastructure, optimization of freight and passenger flows, marketing and logistics centres, innovation, public-private partnership.

Постановка проблеми та ї̈ зв'язки з науковими чи практичними завданнями: Враховуючи сучасні тенденції розвитку світової економіки, економічний розвиток України повинен бути зорієнтований на тип відтворення, який забезпечить формування конкурентних переваг економічної системи. Вибір стратегії розвитку залізничного транспорту обумовлені низкою факторів і насамперед рівнем інфраструктурного розвитку, виробничо-фінансовим потенціалом, використанням економічного механізму регулювання господарської діяльності, місцем в національній економіці, політикою держави і т.д. Головною метою подальшого функціонування залізничного транспорту має стати створення відповідного рівня його розвитку, який дозволить задовольнити життєво важливі потреби країни і населення в перевезеннях в умовах забезпечення сталого економічного зростання, забезпечивши найшвидший перехід до сучасної інфраструктури, що відповідає запитам та вимогам сучасної економіки. Одним із важливих елементів розвитку сучасної інфраструктури має стати маркетингологістичний підхід її подальшого розвитку.

Аналіз останніх досліджень і публікацій. Маркетинго-логістичний підхід на залізничному транспорті розглядали автори І.Аксьонов, В.Дикань, О.Дороховський, М.Устенко $[8,6,10,7]$ та ін. Вирішенню завдань 3 формування та розвитку системи логістичної інфраструктури досліджували О.Зоріна, Л.Миротін, К.Михайличенко, В.Мікловда, О.Наумова, О.Собкевич, Я.Шевчук $[1,15,4,13,1,4,13]$. Теоретичні проблеми i практичні аспекти транспорту, транспортної інфраструктури стали предметом дослідження вчених: Ю.Бараша, Л.Борисової, О. Гненного, Л.Марценюк, М.Міщенка, Ю.Пащенка, О.Рибіної, М. Шапочки $[16,9,16,12,11,14,6]$ та інших.

Виділення невирішених частин загальної проблеми. Маркетинго-логістичний підхід розвитку сучасної інфраструктури на залізничному транспорті є актуальним в умовах реформування залізничної галузі, а тому потребує подальших досліджень.

Формування цілей статті (постановка завдання). Дослідження тенденції розвитку сучасної інфраструктури залізничного транспорту на основі маркетинго-логістичного підходу розглядається, як створення передумов впровадження оптимальної ринкової структури, що $є$ важливим фактором збереження та посилення 
позицій залізничної галузі на конкурентному транспортному ринку із врахуванням довгострокової перспективи.

\section{Виклад основного матеріалу}

дослідження. Маркетинго-логістичний підхід в сучасних умовах розвитку залізничного транспорту прискорить важливі процеси інтеграції в європейську транспортну систему, оскільки може сприяти не тільки створенню надійних управлінських механізмів взаємозв'язку макроекономічного i мікроекономічного регулювання та діючої інституційної структури для прийняття $\mathrm{i}$ реалізації господарських та управлінських рішень, але й забезпечення формування нових міжнародних маршрутів. Для цього необхідно розробляти оптимальні схеми перевезень, що дозволяють збільшити швидкість доставки вантажів і пасажирів, скоротити відстань перевезення, розвинути транзитний потенціал i підвищити конкурентоспроможність залізничного транспорту. Важливою $€$ реконструкція транспортної системи, будівництво нових сучасних колій, модернізація рухомого складу, що забезпечить доступність, оперативність, комплексність, високу якість обслуговування і гарантію виконання взятих на себе зобов'язань. Тому, як зазначається в роботі [1,с.195], нові умови господарювання українських залізниць вимагають у даний час пошуку нових підходів у взаємовідносинах із споживачами транспортних послуг, а також у власному господарському механізмі. Це обумовлює підвищення уваги до впровадження концепції маркетингу та логістики в діяльність Укрзалізниці.

Аналізуючи дані статистики можна відзначити, що обсяги перевезень стрімко падають. У 2013 р. порівняно із 2012 р. обсяг вантажних перевезень залізничним транспортом зменшився на $3,4 \%$ і становить 441,8 млн. тонн вантажів (або 86 $\%$ від рівня 2007 р.) (табл. 1). При цьому за 2013 рік транзитні перевезення скоротилися на 19,3\%, перевезення у внутрішньому сполученні - на 2,8 \%, імпорт вантажів - на 2,7 \%, збільшено лише обсяг перевезень експортних вантажів на $2 \%$. В поточному році ця тенденція продовжується і за дев'ять місяців 2014 р. падіння обсягів перевезень вантажів становить 7,8 \% порівняно з аналогічним періодом 2013 року.

Таблиия 1

Динаміка перевезень вантажів та пасажирів залізничним транспортом Украӥни за 2007-2014 рр [2]

\begin{tabular}{|l|l|l|l|l|l|l|l|l|}
\hline & 2007 & 2008 & 2009 & 2010 & 2011 & 2012 & 2013 & $\begin{array}{l}2014 \\
\text { січень- } \\
\text { вересень }\end{array}$ \\
\hline $\begin{array}{l}\text { Перевезено вантажів, } \\
\text { млн т }\end{array}$ & 512,5 & 498,8 & 391,2 & 432,5 & 468,4 & 457,5 & 441,8 & 293,8 \\
\hline $\begin{array}{l}\text { Індекси до } \\
\text { попереднього року, \% }\end{array}$ & 107,1 & 97,3 & 78,4 & 110,6 & 108,3 & 97,7 & 96,6 & 92,2 \\
\hline у т.ч. транзит, млн т & 99,9 & 93,3 & 44,8 & 44,5 & 48,7 & 40,9 & 33,0 & 15,3 \\
\hline $\begin{array}{l}\text { Індекси до } \\
\text { попереднього року, \% }\end{array}$ & 133,1 & 93,4 & 48,0 & 99,3 & 109,4 & 84,0 & 80,7 & $92,2^{* *}$ \\
\hline $\begin{array}{l}\text { Перевезено } \\
\text { пасажирів, млн }\end{array}$ & 447,4 & 445,6 & 425,9 & 426,6 & 430,1 & 429,6 & 425,4 & $297,4 *$ \\
\hline $\begin{array}{l}\text { Індекси до } \\
\text { попереднього року, \% }\end{array}$ & 100 & 99,6 & 95,6 & 100,2 & 100,8 & 99,9 & 99,0 & 96,4 \\
\hline
\end{tabular}

Крім того, за підсумками 2013 р зафіксовано зниження ефективності використання вагонного ресурсу в сфері вантажоперевезень. Обіг вантажного вагона зріс на $22 \%$ порівняно 3 2012 p. i досяг 7,54 доби. Обіг навантаженого вагона збільшився в 1,5 рази - до 3,29 доби. Простій вагона під вантажною операцією подовжився 3 35,6 год. у 2012 р. до 56,7 год. у 2013 р. (зростання в 1,6 разу)[3].

Низький рівень організації перевізного процесу та в цілому неефективна робота залізничного транспорту значною мірою обумовлюють скорочення обсягів перевезень.
Експлуатаційний вантажообіг локомотивів у 2013 p. склав 365,3 млрд. ткм брутто, що на $6 \%$ менше 2012 р. Локомотиви в середньому обслуговують відстані в 300-400 км, здійснюючи рух переважно в межах залізниць, до яких вони приписані, тоді як в Європі локомотиви виконують рейси протяжністю 1,3-1,4 тис. км, тобто значно меншим парком і з меншими експлуатаційними витратами перевозиться більше вантажів. Спостерігається невідповідність кількості виробничих потужностей рівню перевезень. Обсяги вантажної роботи в порівнянні 3 початком 90-х років скоротились у 2,5 разу, пасажиропотік - більше 
ніж на третину, тоді як виробничі потужності (локомотивні та вагонні депо, дистанції колії та інше) практично не скорочувались. Високим $\epsilon$ показник чисельності персоналу на 1 км експлуатаційної довжини шляхів, який на українських залізницях становить 17 чол., тоді як, наприклад, у Білорусі - 14, у Росії - 12 чол., а в США - 1,2 працюючих на 1 км (найменша у світі)[4]

Нові підходи у вирішенні проблем поліпшення транспортного обслуговування залежить від стану транспортної інфраструктури, де залучаючи приватний капітал в оновлення рухомого складу можна задовольнити рівень попиту на залізничні перевезення в умовах посилення конкурентної боротьби, що в цілому підвищить якість сервісу. Тобто, пріоритетом повинно стати не лише придбання необхідної кількості одиниць рухомого складу переважно нового покоління, що відповідає європейським технічним нормам, а й надання можливості приватним компаніям вийти на ринок перевезень (надати необхідні ліцензії, доступ до залізничних колій та мереж тощо). При цьому умови оплати за використання інфраструктури мають бути однакові для всіх перевізників, включаючи й Укрзалізницю [5,c.619].

Можна константувати, що маркетингологістична підтримка особливо вантажопотоків на залізничному транспорті здійснюється неефективно, що знижує якість роботи залізничного транспорту. Тому необхідними умовами здійснення ефективної маркетингологістичної діяльності на залізничному транспорті в умовах реформування повинно бути: розуміння керівництвом Укрзалізниці важливості переорієнтації діяльності на концепцію маркетингу та логістики, впровадження їх в діяльність підприємств, виконання ними суто профільних функціональних обов'язків, налагоджено системи планування і контролю, що дозволить зменшити кількість нераціональних перевезень.

Уникнення нераціональних перевезень на залізничному транспорті, невиправданих дальніх, зустрічних, порожніх пробігів, а також повторних перевезень, коли вантаж повторно перевозиться, розвантажується і завантажується на складських підприємствах посередницьких організацій можна буде забезпечити, як зазначає автор [6,c.147] створенням інфраструктури міжнародних транспортних коридорів, як невід'ємної частини високошвидкісної магістралі, глобальної транспортно-логістичної системи, дозволить забезпечити потреби вітчизняних підприємств у сучасних транспортно-логістичних послугах, за рахунок гармонізації їх інтересів 3 інтересами всіх учасників транспортно-розподільчого процесу, створити гнучку тарифну політику на різних видах транспорту 3 метою збільшення міжнародних вантажопотоків на основі формування оптимальних схем доставки вантажу на принципі «від дверей до дверей».

Для транспортної системи будь-якої держави активна участь у глобалізації ринку транспортних послуг означає: лібералізацію усіх сфер транспортної діяльності, відмову від державного регулювання, що спричинюється, отже, до зростання конкуренції; уніфікацію i універсалізацію транспортних засобів, технологій, технічних вимог, активний розвиток i модернізацію транспортної інфраструктури; зростання транспарентності ринку транспортних послуг, зростання інформаційної відкритості (зокрема фінансову інформацію), підпорядкування діяльності транспортних компаній вимогам законодавства і міжнародних угод [7,c.3].

Глобалізація транспортних процесів висувають нові вимоги до управління сервісними потоками в маркетинго-логістичних системах залізничного транспорту. Якісний інформаційний та сервісний супровід вантажопотоків в рамках логістичної системи залізничного транспорту, використовуючи маркетингові можливості транспортних фірм, дозволить забезпечити інтеграцію і координацію всіх учасників руху товару, створить передумови для оптимізації витрат руху товару $[8, \mathrm{c.188}]$ і підвищить ефективність залізничних перевезень. Тому не можна не відзначити, що логістичну концепцію використовують й інші види транспорту, зокрема морський, де в роботі [9, с.87], зазначається, що основні завдання, які ставляться транспортним організаціям, передбачають зниження вартості перевезень, поліпшення їх якості, скорочення термінів доставки, гармонійне поєднання на ринку транспортних послуг усіх видів сучасного транспорту. Вирішенню цих завдань можуть сприяти, зокрема, морські логістичні кластери, які дозволять: збільшити вантажопотоки, що позитивно вплине на подальший розвиток експорту; значно підвищити продуктивність праці за рахунок діючої ефективної системи спеціалізації портів на обробці певних вантажів; впровадити використання сучасних ефективних транспортних логістичних концепцій, які сприятимуть зменшенню витрат перевізника, що, в свою чергу, знизить вартість перевезень; створити в рамках морського логістичного кластера навчальні центри і курси 3 підготовки фахівців у галузі логістики; організувати та забезпечити роботою підприємства малого i середнього бізнесу; розвивати підприємства і компанії рекреаційної та туристичної галузей. 
Застосування маркетинго-логістичної концепції в діяльності залізничного транспорту пов'язане 3 необхідністю оптимізації сукупних експлуатаційних витрат руху товару, складністю багатокритеріальних задач перевізного процесу, що в свою чергу обумовлює необхідність ідентифікації виникнення, спрямованості, інтенсивності i швидкості сервісних потоків, супроводжуючих перевезення. Оптимізація вантажопотоків у рамках логістичного центру на основі їх інформаційного та сервісного супроводу дозволить забезпечити інтеграцію і координацію всіх учасників руху товару, підвищить ефективність залізничних перевезень.

В умовах нової розстановки сил на світовій арені та випереджаючого розвитку країн Азії, Україна має неабиякі можливості реалізації свого транзитного потенціалу. Суверенізація України і перехід до ринкової економіки визначили необхідність застосування логістичного підходу до вирішення зазначених та інших проблем функціонування транспорту. Основна мета транспортної логістики полягає в наданні необхідних транспортних послуг у галузях постачання, збуту та переробки відходів 3 мінімальними витратами [10, с.65].

Отже, виникає необхідність в узгодженому взаємодії при фінансуванні модернізації та розвитку інфраструктури залізничного транспорту, враховуючи маркетинго-логістичний підхід. Поспішне реформування залізниць різко збільшить транспортну складову у вартості будьякої продукції, a, значить, підвищить всі споживчі ціни і тарифи, обмежить доступність поїздок для більшості громадян неконкурентоспроможним вітчизняний експорт. Тут виникає потреба у держвному регулюванні. В роботі [11, с.105] автор зазначає, що державному регулюванню підлягають: розвиток i технічне вдосконалення державної й регіональної інфраструктури; інституційні перетворення на транспорті; питання технологічної й екологічної безпеки роботи транспорту; формування й функціонування ринку транспортних послуг; забезпечення мобілізаційної готовності транспорту; міжнародна діяльність транспортних підприємств і структур.

Принципи організації визначення (прогнозування), формування (розвитку) та реалізації (ефективного використання) партнерських відносин на залізничному транспорті у сфері фінансування інфраструктурних об'єктів забезпечить створення принципово нової моделі організації виробництва, орієнтованої на створення інновацій та зорієнтоване на конкурентне середовище, що вимагає внесення змін до деяких законодавчих актів України щодо зняття регуляторних бар“єрів для розвитку державно-приватного партнерства в Україні та стимулювання інвестицій.

Необхідність ефективного державного регулювання пов'язана із забезпеченням виконання завдань по модернізації інфраструктури, адже внутрішні ресурси залізничної галузі не дозволяють кардинально вирішити проблему модернізації основних виробничих фондів за рахунок власних джерел $\mathrm{i}$, отже, як найважливішого аспекту даної проблеми слід виділити відпрацювання фінансових схем залучення зовнішнього капіталу в розвиток транспортних підприємств. Для інвестора найбільш привабливими виглядають угоди, де він має можливість отримати права на майно, створене на його власні кошти, проте відносно обмеженого в обороті майна такого роду угоди неприйнятні. Як показує досвід [12, с.63], у обох видів власності $є$ як позитивні, так і негативні сторони. 3 одного боку, саме на державних залізницях $є$ умови для створення та впровадження нових технологій, таких як високошвидкісні поїзди, розробка яких, як i будівництво спеціалізованих ліній, були б неможливі без наявності відповідної науководослідної бази, а також без державного фінансування. 3 іншого, - приватні підприємства, що працюють на концесійній основі, як правило, надають послуги більш високого рівня за прийнятними тарифами, тобто логістична система передбачає одночасне рішення чотирьох завдань: технологічної, технічної, економічної та управлінської.

Оскільки внутрішні ресурси галузі не дозволяють кардинально вирішити проблему модернізації інфраструктури за рахунок власних джерел i, отже, як найважливішого аспекту даної проблеми слід виділити відпрацювання фінансових схем залучення зовнішнього капіталу в розвиток транспортних підприємств. Необхідно обов'язково і по-справжньому реформувати залізничний транспорт після необхідного опрацювання, експертиз та публічного обговорення, реальної оцінки основних фондів і прийняття програми розвитку транспорту на перспективу. Поспішне реформування залізниць різко збільшить транспортну складову у вартості будь-якої продукції, a, значить, підвищить всі споживчі ціни і тарифи, обмежить доступність поїздок для більшості громадян i зробить неконкурентоспроможним вітчизняний експорт. Для інвестора найбільш привабливими виглядають угоди, де він має можливість отримати права на майно, створене на його власні кошти. Можна зацікавити інвесторів в створенні маркетинго-логістичних центрів. Це забезпечить 
"Укрзалізниці"провести реформування моделі управління бізнесом, здійснити трансформацію організаційної структури шляхом впровадження бізнес-процесів та інструментів управління ефективністю, які будуть відповідати кращим світовим практикам, підвищити ефективність та прозорість комерційних операцій компанії, і як наслідок - зростання фінансових результатів. Це дозволить гарантувати стратегічну стійкість компанії під час кризових процесів. Об'єктивна необхідність використання маректингологістичних принципів на залізниці призведе до появи структури, що здійснює вплив на інфраструктуру виконуючи координаційні та комунікативні функції при управлінні пасажирота вантажопотоками.

\section{Висновки даного дослідження $i$} перспективи подальщих робіт у цьому напрямку. Маркетинго-логістичне забезпечення розвитку інфраструктури буде сприяти ефективному управлінню вантажопотоками та пасажиропотоками на залізницях 3 використанням комплексу взаємопов'язаних інформаційнокеруючих систем, що дозволить здійснювати технологічний взаємозв'язок із суміжними організаціями транспортного процесу, що в подальшому сприятиме створенню інтегрованих транспортно-логістичних ланцюгів 3 урахуванням системних методів управління, спрямованих на досягнення його сталого розвитку, що дозволить сформувати довгострокову стратегію розвитку залізниць України і дорожню карту іiі реалізації. Розробити і послідовно втілити план заходів щодо зниження витрат і оптимізації бізнес-процесів; забезпечити ефективне впровадження стратегії розвитку та проходження організації через всі етапи реформування. Створенні та раціонально розміщені маркетинго-логістичні центри сприятимуть переходу на зорієнтовану на клієнта модель надання послуг пасажирських і вантажних перевезень. Проте, необхідно обов'язково і посправжньому реформувати залізничний транспорт після необхідної опрацювання, експертиз та публічного обговорення, реальної оцінки основних фондів і прийняття програми розвитку транспорту на перспективу. Також необхідно внести зміни до деяких законодавчих актів України щодо зняття регуляторних бар'єрів для розвитку державно-приватного партнерства в Україні та стимулювання інвестицій. Вплив маркетину та логістики на інфраструктуру залізничного транспорту України - одне 3 нових наукових напрямів в теорії i практиці. Ця проблема ще не достатньо вивчена, що і визначає актуальність подальших досліджень.

\section{СПИСОК ЛІТЕРАТУРИ}

1. Зоріна O.I. Застосування концепції інтегрованого маркетингу на залізничному транспорті в умовах реформування галузі / Зоріна O.I., Наумова O.Е., Антонова O.I. // БІЗНЕСІНФОРМ (Економіка: менеджмент i маркетинг). - 2012. - №8 . - С191-195.

2. Складено за даними: Транспорт і зв'язок, статистична інформація // Офіційний сайт Держкомстату [Електронний ресурс]. Режим доступу: http://www.ukrstat.gov.ua/

3. На сети «Укрзализныци» ухудшились показатели использования грузового вагонного парка [Електронний ресурс]. - Режим доступу: http://railwaypublish.com/index.php?page $=$ news\&s $=2$

$\& y=2014 \& m=1 \&$ start $=10$

4. Михайличенко К.М., Собкевич О.В. Удосконалення механізмів реформування та розвитку залізничного транспорту в контексті реалізації структурних реформ в галузі.Аналітична записка / Михайличенко К.М., Собкевич О.В. // № 37, Серія «Економіка». Національний інститут стратегічних досліджень при Президентові України. Режим доступу: http://www.niss.gov.ua/articles/1662/

5. Шапочка М.К. Впровадження європейського досвіду в оптимізацію інфраструктури залізничного транспорту України / Шапочка М.К., Рибіна O.I. // Збірник наукових праць Національного університету державної податкової служби України. - 2011. - № 1. C.615-623.

6. Дикань В.Л. Перспективы развития экономики украины в условияхформирования международных транспортных коридоров в системе мировой глобализации экономики / Дикань В.Л. // Вісник економіки транспорту i промисловості. - 2013. - № 42. - С.144-149.

7. Устенко М.О. Основні проблеми транспортної логістики УкрДАЗТ/ Устенко М.О. // Вісник економіки транспорту і промисловості.2010.- N29.- C. 2-5.

8. Аксенов И. М. Маркетинг на объектах транспорта :монография / И. М. Аксенов. Нежин: ООО Вид-во «Аспект-Поліграф», 2006. $336 \mathrm{c}$.

9. Борисова Л.П. Основні проблеми та перспективи розвитку транспортної логістики в Україні./ Борисова Л.П. // Економіка. Управление. Інновації.. - 2013. - Випуск № 2 (10). - С.79-88.

10. Дороховський О.М. Проблеми та перспективи розвитку транспортно-логістичної системи України / Дороховський О.М. // Экономика и управление.-2012 -№ 5. (Региональная экономика). - С.60-65. 
11. Міщенко М.I. Економіко-організаційні основи функціонування підприємств колійної інфраструктури: монографія / М.І.Міщенко. Одеса: ІПРЕЕД НАН України, 2013. - 492с.

12. Марценюк Л.В. Огляд досвіду реформування провідних залізниць світу / Марценюк Л.В. // Наука та прогрес транспорту. Вісник Дніпропетровського національного університету залізничного транспорту. - 2013. вип. 1 (43). - С.63-81.

13. Мікловда В.П. Сучасний стан та рівень розвитку автомобільної інфраструктури України [Електронний ресурс] / В.П. Мікловда, Я.В. Шевчук.

Режим
14. Пащенко Ю.С. Проблеми та перспективи розвитку транспортно-дорожного комплексу у період трансформації економіки України / Пащенко Ю.С. // Формування ринкових відносин в Україні. - 2006. - №2 (57). - С. 94-97.

15. Миротин Л. Б. Транспортная логистика: учебник / учеб пособие для студентов вузов/ Л. Б. Миротин, И. Э. Ташбаев, В. А. Гудков; под ред. Л. Б. Миротина. - М. Экзамен, 2003. $512 \mathrm{c}$.

16. Бараш Ю.С. Розробка концепції впровадження швидкісного та високошвидкісного руху пасажирських поїздів на залізницях України в 2005- 2015 роках / Бараш Ю.С., Гненний О.М. // Дніпропетр. нац. ун-т. заліз. трансп. ім. акад. В. Лазаряна, - Дніпропетровськ - 2004.

Експерт редакційної колегії к.е.н., доцент УкрДАЗТ Зубенко В.О.

УДК 658.7:656.2

\title{
РОЗРОБКА КОМПЛЕКСНОГО МЕХАНІЗМУ РОЗВИТКУ ТРАНСПОРТНО- ЛОГІСТИЧНОЇ ІНФРАСТРУКТУРИ ЗАЛІЗНИЦЬ
}

\author{
Кузьменко А.В., аспірант (УкрДАЗТ)
}

\begin{abstract}
В статті визнано, щзо для сучасного споживача транспортних послуг надзвичайно важливим виступає отримання комплексного транспортно-логістичного обслуговування від єдиного мобільного перевізника та логістичного оператора. Встановлено, щяо через низький рівень розвитку об'єктів транспортно-логістичної інфраструктури та існування ряду інших галузевих причин, на сьогоднішній день залізничний транспорт України не має змоги надавати повний комплекс транспортно-логістичних послуг, а, відповідно, й виступати єдиним транспортно-логістичним оператором в країні. На основі цього розроблено комплексний механізм розвитку транспортно-логістичної інфраструктури залізниць та визначено його характерні особливості. Виділено комплекс основних завдань, які сприятимуть створенню умов для якісного вдосконалення стану та структури транспортно-логістичної інфраструктури Укрзалізниці, подано принциипи, методи та інструменти ї̈ розвитку.
\end{abstract}

Ключові слова: механізм, транспортно-логістична інфраструктура, залізничний транспорт, розвиток, методи, інструменти.

\section{РАЗРАБОТКА КОМПЛЕКСНОГО МЕХАНИЗМА РАЗВИТИЯ ТРАНСПОРТНО- ЛОГИСТИЧЕСКОЙ ИНФРАСТРУКТУРЫ ЖЕЛЕЗНЫХ ДОРОГ}

\author{
Кузьменко А.В., аспирант (УкрГАЖТ)
}

В статье признано, что для современного потребителя транспортных услуг чрезвычайно важным является получение комплексного транспортно-логистического обслуживания от одного мобильного перевозчика и логистического оператора. Установлено, что в связи с низким уровнем развития объектов транспортно-логистической инфраструктуры и существованием ряда других отраслевых причин, на сегоднячний день железнодорожный транспорт Украины не имеет возможности предоставлять полный комплекс транспортно-логистических услуг, а, соответственно, и выступать единым транспортно-логистическим оператором в стране. На основе этого разработан комплексный механизм развития транспортно-логистической инфраструктуры железных дорог, определены его характерные особенности. Выделен комплекс основных задач, которые будут способствовать созданию условий для качественного совершенствования состояния и структуры 